\title{
Seroprevalence of Anti-HCV Antibody in Patients with Chronic Kidney Disease before Starting Dialysis Therapy
}

\author{
Fareha Jesmin Rabbi ${ }^{1}$, Kaniz Fatema ${ }^{2}$, Md. Morshed Alam ${ }^{3}$ \\ Received: May 10, 2016 Accepted: November 27, 2016 \\ doi: http://dx.doi.org/10.3329/jemc.v7i1.30746
}

\begin{abstract}
Background: Hepatitis $C$ virus (HCV) infection and chronic kidney disease are common and potentially serious medical problems throughout the world. In recent years, it has become clear that these two conditions are linked in several important ways. Indeed, some forms of renal diseases are precipitated by HCV infection and patients with end-stage renal disease (ESRD) are at increased risk for acquiring HCV infection. Patients with chronic kidney disease typically show an impaired immune response compared with healthy individuals and also other risk factors related with treatment and management. CKD patients ultimately undergo end stage renal therapy like dialysis for their treatment and survival. Risk factors for the infections are more in dialysis period than in predialytic stages. Like other developing countries CKD patients with HCV infection are very common in our country. For this reason the CKD patients should be properly diagnosed knowing the infection status before dialysis which would help both the patient and doctor to choose their proper treatment approach. Objective: This cross-sectional study was done to know the prevalence of HCV infection in the CKD patients before starting dialysis therapy. Materials and Methods: A total of 197 patients with chronic kidney disease stage five $(C K D-V)$ before starting dialysis therapy were included as subjects of this study. Among the CKD patients anti-HCV was detected to see prevalence of hepatitis $C$ virus infection. The patients were also tested for HBsAg to assess co-infection. After collecting all the data of different test results analyses were done by SPSS version 15.0. Results: In this study 195 (99\%) patients were anti-HCV negative and only two patients (1\%) were found positive. Conclusion: HCV infection in CKD patients before dialysis should be taken into account so that HCV negative CKD patients would not get the infection during dialysis and standard screening procedures should be taken to prevent transmission of infection.
\end{abstract}

Key words: Chronic kidney disease; HCV infection; Dialysis

J Enam Med Col 2017; 7(1): 20-24

\section{Introduction}

Chronic kidney disease (CKD) has a prevalence of $10.3-13.7 \%$ in different countries ${ }^{1}$ and its incidence is rising throughout the world. ${ }^{2,3}$ Patients with end-stage renal disease (ESRD) are at increased risk for acquiring different infections like HCV infection. ${ }^{4}$ The role of $\mathrm{HCV}$ in the course, morbidity, and mortality of renal disease is often not adequately considered in the care of patients with CKD. More than 170 million people worldwide are chronically infected with the hepatitis $\mathrm{C}$ virus $(\mathrm{HCV})$ which is responsible for over one million deaths from cirrhosis and primary liver cancers. ${ }^{5}$ Beside chronic liver disease, relevant extrahepatic manifestations of $\mathrm{HCV}$ infection include

1. Associate Professor, Department of Clinical Immunology, National Institute of Kidney Diseases and Urology, Dhaka

2. Assistant Professor, Department of Clinical Immunology, National Institute of Kidney Diseases and Urology, Dhaka

3. Assistant Professor, Department of Biochemistry, National Institute of Kidney Diseases and Urology, Dhaka

Correspondence Fareha Jesmin Rabbi, Email: fjesminr@yahoo.com 
cryoglobulinemia, lymphoproliferative disorders, and renal diseases. ${ }^{6}$ So both HCV infection and chronic renal disease are common and potentially serious medical problems throughout the world and are linked in several important ways.

$\mathrm{HCV}$ infection is transmitted primarily through the parenteral route. Other modes of transmission like sexual, vertical routes also have some role in transmission. Some studies have shown that nosocomial transmission is not rare. CKD patients are at increased risk of acquiring HCV infection as a result of nosocomial spread or exposure to infected blood and blood products. Although some risk factors for acquiring $\mathrm{HCV}$ infections are present in $50 \%$ cases, no recognizable transmission factor could be identified in the remaining 50\%.,8 While the risk of transmission of the virus has been considerably reduced in developed countries owing to increased screening procedures ${ }^{9-11}$, the problem is not properly addressed in developing countries like Bangladesh. As hepatitis B virus (HBV) and hepatitis $\mathrm{C}$ virus (HCV) have common modes of transmission, presence of co-infection of both HCV and $\mathrm{HBV}$ in patients is not rare, and is relatively high in transfusion recipients. ${ }^{12-14}$

HCV infection is a common complication of the treatment of CKD patients. In a recent multinational cohort study the reported prevalence of $\mathrm{HCV}$ infection in hemodialysis units of developed countries has ranged from 2.6-22.9\% (with a mean of $13.5 \%$ ). But prevalence may be as high as $70 \%$ in developing countries. ${ }^{15,16}$

Like in other developing countries, CKD patients with HCV infection is very common in our country. Patients with chronic kidney disease typically show an impaired immune response compared with healthy individuals. Varieties of inherited or acquired factors have been implicated in this diminished immune response. CKD patients ultimately undergo end stage renal therapy like dialysis for their treatment and survival. Risk factors for the infections are more in dialysis period than predialytic stages. In dialysis period there is more chance to get infection by the dialysis machine through blood products, use of contaminated equipments and sometimes by nosocomial infection. For this reason the CKD patients should be properly investigated for $\mathrm{HCV}$ before starting dialysis. This will help the physician to choose suitable dialysis machine for the patient and the site where the patient should be kept for dialysis to prevent transmission of HCV. Blood products must be properly screened and used by sterile technique.

We should have knowledge about HCV infections in CKD patients before dialysis as immune response is reduced in CKD patients compared to healthy individuals and the patient may get infection during the course of management. A very few studies are available regarding prevalence of $\mathrm{HCV}$ in CKD patients before dialysis. ${ }^{17}$ In this study it has been attempted to determine the prevalence of anti-HCV antibody in the predialysis CKD patients, which will help in the development of awareness and stringent screening procedure to reduce the transmission of infection.

\section{Materials and Methods}

This cross-sectional study was carried out in National Institute of Kidney Diseases and Urology Hospital during the period from July 2011 to June 2012. A total of 197 patients with chronic kidney disease stage five (CKD-V) [estimated glomerular filtration rate (eGFR) $<15$ $\mathrm{mL} / \mathrm{min} / 1.73 \mathrm{~m}^{2}$ for $\geqslant 3$ months] before starting dialysis therapy were included in this study. Patients with CKD admitted in the hospital were tested and included as subjects of this study. CKD stage five was assessed according to the relevant history and based on age, sex and serum creatinine value. According to Kidney Disease Outcome Quality Initiative (KDOQI) guideline patients with estimated GFR $<15 \mathrm{~mL} / \mathrm{min} / 1.73 \mathrm{~m}^{2}$ for $\geqslant 3$ months were considered as CKD-V cases. ${ }^{18}$ Estimated GFR was calculated from serum creatinine level by using Modification of Diet in Renal Disease (MDRD) prediction equation: GFR $\left(\mathrm{mL} / \mathrm{min} / 1.73 \mathrm{~m}^{2}\right)=186 \times(\mathrm{Scr})^{-1.154} \times$ $(\text { Age })^{-0.203} \times(0.742$ if female $)$.

Anti-HCV was detected (by ELISA, Human GmbHGermany) to see hepatitis $C$ virus infection among the CKD patients. The discovery of HCV in 1989 led to the development of an antibody diagnostic assay (anti-HCV) based on viral recombinant peptides. The third generation assays (ELISA-3) have been introduced incorporating antigens from putative neucleocapsid, NS3, NS4, and NS5 regions, and become positive in $2-3$ weeks after the infection. ${ }^{19}$ These are currently the most widely used screening tests for HCV and are more sensitive and specific than earlier generation tests in screening blood donors. ${ }^{20}$ The patients were also tested for HBsAg to assess coinfection. After collecting all the data of different test results, analyses were done by SPSS version 15.0. 


\section{Results}

In this study, total 197 CKD patients before starting dialysis therapy were included. Among them 116 were male and 81 were female with mean age $43.93 \pm 15.68$ years. All patients were tested for anti-HCV. Of them 195 (99\%) patients were anti-HCV negative and only two patients $(1 \%)$ were found positive for anti-HCV. Both these anti-HCV positive patients were male.

Table 1: Seroprevalence of anti-HCV among study population $(\mathrm{N}=197)$

\begin{tabular}{|l|c|c|}
\hline Sex & Anti-HCV +ve & Anti-HCV-ve \\
\hline Male $(n=116)$ & 2 & 114 \\
\hline Female $(n=81)$ & 0 & 81 \\
\hline
\end{tabular}

\section{Discussion}

Hepatitis is the third most common cause of mortality in CKD patients. So prevention and treatment of hepatitis gains more importance in the treatment of CKD patients. ${ }^{21-23}$ In our country where both hepatitis and CKD are endemic, it can be considered that exposure of CKD patients to hepatitis virus is natural. Both HBV and HCV infections are well known causes of CKD and also these infections may occur as a consequence of CKD management. Extrahepatic manifestations are more common with $\mathrm{HCV}$ infection than with HBV infection. Renal failure is an important extrahepatic complication of $\mathrm{HCV}$ infection. Liver disease in these patients may be mild or even clinically absent. ${ }^{24}$ Probable association between HCV infection and renal disease was first reported in $1990 .^{25}$ Subsequently, Johnson et al demonstrated a strong association between HCV infection and membranous proliferative glomerulonephritis (MPGN). ${ }^{26}$ Various other forms of renal disorders like minimal change nephropathy (MGN), IgA nephropathy, focal segmental glomerulosclerosis (FSGS) have been described in subsequent studies. ${ }^{27-29}$

A very few studies are available regarding $\mathrm{HCV}$ prevalence in general population in our country. According to a study ${ }^{30}$ conducted by ICDDRB at Kamlapur, Dhaka, 1997 participants (general population) were screened for anti-HCV. Four $(0.2 \%)$ participants were positive for anti-HCV. ${ }^{30}$ In another study $^{31}$ conducted in a semi-urban location on the outskirts of Dhaka, 1018 individuals of different age groups and sex with varied religious, educational and social backgrounds were tested for anti-HCV by ELISA. Of them $0.88 \%$ tested positive for anti $\mathrm{HCV}$; but none of them tested positive for HBsAg. There was a male predominance and those who tested positive were mostly between 17 and 50 years of age. ${ }^{31}$ Most of the previous studies regarding $\mathrm{HCV}$ prevalence were conducted in different selected groups of people. ${ }^{32-35}$ The prevalence of anti-HCV was reported from high risk groups of Dhaka: $0.8 \%$ among truck drivers and helpers $^{32} ; 0.9 \%$ among women at a STD clinic $^{33} ; 1.6 \%$ among women living near a truck stand ${ }^{34} ; 5.8 \%$ in noninjectable drug users (non-IDUs) and $24.8 \%$ in IDUs ${ }^{35}$; and $13 \%$ among hepatitis patients ${ }^{36}$.

We also decided to estimate the prevalence of anti-HCV in a high risk population group like CKD patients. It is evident that HCV infection is one of the major global health problems, and rapidly spreading in developing countries due to the lack of health education, poverty, and illiteracy. As many chronically infected individuals remain asymptomatic, they can be undetected for many years. Immune response is reduced in CKD patients compared to healthy individuals and the patient may get infection during the course of management. The high rate of HCV transmission among CKD patients may be due to direct exposure to infectious blood and/or blood products because of inadequate infection control. Cross contamination between patients can occur in dialysis units because of lack of disinfection of commonly utilised medical equipment and supplies, use of shared vials of heparin, and blood spills which are not immediately cleaned. ${ }^{37} \mathrm{HCV}$ infection is a complicating factor in patient with ESRD on maintenance dialysis or after kidney transplantation. As the dialysis patients are higher risk group to get the infections, there may be discrepancy in pre-dialysis and dialysis period regarding these infections.

In India, on an average, HCV prevalence was reported as $1.5-2.7 \% .^{38,39}$ In CRF patients with a history of either renal transplantation or hemodialysis $46 \%$ were found infected with $\mathrm{HCV}$ alone. ${ }^{40}$ In Turkey, in predialysis and hemodialysis patients prevalence of anti-HCV was $7 \%$ and $19.3 \%$ respectively and coexistence of positive HBsAg and anti-HCV was $0.6 \%$ and $1.5 \%$ respectively in different studies. ${ }^{17,41}$ In Bangladesh, around $71 \%$ of patients on maintenance hemodialysis were serologically positive for hepatitis $\mathrm{C}$ virus infection. ${ }^{42}$ 
In our country, a very few data regarding hepatitis $\mathrm{C}$ virus in predialytic CKD patients is available. In one study in which 63 maintenance hemodialysis patients and 25 predialytic patients were included as study subjects, the researchers found 24 (38\%) maintenance hemodialysis (MHD) patients and none of the predialytic patients positive for anti-HCV. ${ }^{43}$ In the present study among 197 predialytic CKD patients 2 (1\%) were found anti-HCV positive, which differ from the above study. No patient was found positive for both $\mathrm{HBsAg}$ and anti-HCV. Detection of anti-HCV indicates present or previous $\mathrm{HCV}$ infection but cannot discriminate acute from chronic or resolved $\mathrm{HCV}$ infection.

Presence of HCV-RNA in the serum is taken as an indicator for active infection where anti-HCV may not be present initially in acute infection. ${ }^{44} \mathrm{We}$ did not perform some diagnostic tests for $\mathrm{HCV}$, e.g., recombinant immunoblot assay (RIBA) to confirm $\mathrm{HCV}$ exposure, or polymerase chain reaction (PCR) to detect HCV-RNA in the HCV infected individuals. All these limitations are mainly due to study-cost constraints. As because the study was conducted in a single population of a hospital, it may not reflect overall scenario. The HCV prevalence in our study roughly correlates with the other studies in general population. ${ }^{30,31}$ Acute $\mathrm{HCV}$ infection cases were missed as we did not perform HCV RNA. So further studies will be needed to expose the hidden cases. For follow-up of the patients repeat anti-HCV testing is necessary to reduce the transmission of infection. Simple measures such as enforced general asepsis rules, careful disinfection and equipment sterilisation are needed to prevent transmission of infection. Standard screening procedures and precautions should be taken in blood donation.

\section{References}

1. Ayodele OE, Alebiosu CO. Burden of chronic kidney disease: an international perspective. Adv Chronic Kidney Dis 2010; 17: 215-224.

2. Foley RN. Temporal trends in the burden of chronic kidney disease in the United States. Curr Opin Nephrol Hypertens 2010; 19: 273-277.

3. Stengel B, Billon S, VanDijk PC, Jager KJ, Dekker FW, Simpson K et al. Trends in the incidence of renal replacement therapy for end-stage renal disease in Europe, 1990-1999. Nephrol Dial Transplant 2003; 18: 1824-1833.

4. Meyers CM, Seeff LB, Stehman-Breen CO, Hoofnagle JH.
Hepatitis $\mathrm{C}$ and renal disease: an update. Am J Kidney Dis 2003; 42: 631-657.

5. Poynard T, Yuen MF, Ratziu V, Lai CL. Viral hepatitis C. Lancet 2003; 362: 2095-2100.

6. Cacoub P, Costedoat-Chalumeau N, Lidove O, Alric L. Cryoglobulinemia vasculitis. Curr Opin Rheumatol 2002; 14: 29-35.

7. Hepatitis C. Available at: http://who.int/mediacentre/ factsheets/fs164/en/. Accessed July 2016.

8. Memon MI, Memon MA. Hepatitis C: an epidemiological review. J Viral Hepat 2002; 9: 84-100.

9. Arankalle VA, Chobe P, Banerjee K. HCV in Pune. J Assoc Physicians India 1992; 40: 562.

10. Baur P, Daniel V, Pomer S, Scheurlen H, Opeiz G, Roelcke D. HCV in kidney recipients: epidemiology and impact on renal transplantation. Ann Hematol 1991; 62: 68-73.

11. Bruguera M, Vidal L, Sanchez-Tapias JM, Costa J, Revert L, Rodes J. Incidence and features of liver disease in patients on chronic hemodialysis. J Clin Gastroentrol 1990; 20: 5042-5045.

12. Sato S, Fujiyama S, Tanaka M, Yamasaki K, Kuramoto I, Kawano $\mathrm{S}$ et al. Co-infection of hepatitis $\mathrm{C}$ virus in patients with chronic hepatitis B infection. J Hepatol 1994; 21: 159-166.

13. Pontisso P, Gerotto M, Benvegnu L, Chemello L, Alberti A. Coinfection by hepatitis $\mathrm{B}$ virus and hepatitis $\mathrm{C}$ virus. Antivir Ther 1998; 3(Suppl): 137-142.

14. Sumathy S, Valliammai T, Thyagarajan SP, Malathy S, Madanagopalan N, Sankaranarayanan VS. Prevalence of $\mathrm{HCV}$ infection in liver diseases, renal diseases and VBDs in South India. Indian J Med Microbiol 1993; 11: 291-297.

15. Fissell RB, Bragg-Gresham JL, Woods JD, Jadoul M, Gillespie B, Hadderwick SA et al. Patterns of hepatitis C prevalence and seroconversion in hemodialysis units from three continents: the DOPPS. Kidney Int 2004; 65(6): 2335-2342.

16. Karkar A. Hepatitis $C$ in dialysis units: the Saudi experience. Hemodial Int 2007; 11: 354-367.

17. Sit D, Kadiroglu AK, Kayabasi H, Yilmaz ME, Goral V. Seroprevalence of hepatitis B and C viruses in patients with chronic kidney disease in the predialysis stage at a University Hospital in Turkey. Intervirology 2007; 50: 133-137.

18. National Kidney Foundation. KDOQI Kidney Disease Outcome Quality Initiative. Am J Kidney Dis 2002; 39: S1-S266.

19. Barrera JM, Francis B, Ercilla G, Nelles M, Achord D, Darner et al. Improved detection of anti-HCV in posttransfusion hepatitis by a third generation ELISA. Vox Sang 1995; 68: 15-18. 
20. Courouce AM, Bouchardeau F, Girault A, Le Marrec N. Significance of NS3 and NS5 antigens in screening for HCV antibody. Lancet 1994; 343: 353-354.

21. Registry of the Nephrology, Dialysis and Transplantation in Turkey. Registry, 2004.

22. Akpolat T, Arik N, Gunaydin M, Utas C, Dilek K, Caglar S et al. Prevalence of anti-HCV among hemodialysis patients in Turkey: a multicenter study. Nephrol Dial Transplant 1995; 10: 479-480.

23. Dundar IH, Inal AS. Viral hepatitis from past to today. In: Tabak F, Balik I, Tekeli E (eds). Viral Hepatitis 2005 (in Turkish). Istanbul, Society of Struggle against Viral Hepatitis Publication 2005: 10-20.

24. Radhakrishnan J, Uppot RN, Colvin RB. Case records of the Massachusetts General Hospital. Case 5-2010. A 51-yearold man with HIV infection, proteinuria and edema. N Engl J Med 2010; 362: 636-646.

25. Pascual M, Perrin L, Giostra E, Schifferli JA. Hepatitis C virus in patients with cryoglobulinemia type II. J Infect Dis 1990; 162: 569-570.

26. Johnson RJ, Gretch DR, Yamabe H, Hart J, Bacchi CE, Hartwell $\mathrm{P}$ et al. Membranoproliferative glomerulonephritis associated with hepatitis $\mathrm{C}$ virus infection. $\mathrm{N}$ Eng $\mathrm{J}$ Med 1993; 328(7): 465-470.

27. Stehman-Breen C, Alpers CE, CousernWG, Willson R, Johnson RJ. Hepatitis C virus associated membranous glomerulonephritis. Clin Nephrol 1995; 44(3): 141-147.

28. Sabry AA, Sobh MA, Irving WL, Grabowska A, Wagner BE, Fox $\mathrm{S}$ et al. A comprehensive study of the association between hepatitis $\mathrm{C}$ virus and glomerulopathy. Nephrol Dial Transplant 2002; 17: 239-245.

29. Roccatello D, Fornasieri A, Giachino O, Rossi D, Beltrame A, Banfi $G$ et al. Multicenter study on hepatitis $C$ virus related cryoglobulinemic glomerulonephritis. Am J Kidney Dis 2007; 49(1): 69-82.

30. Ashraf H, Alam NH, Rothermundt C, Brooks A, Bardhan $\mathrm{P}$, Hossain L et al. Prevalence and risk factors of hepatitis B and $\mathrm{C}$ virus infections in an impoverished urban community in Dhaka, Bangladesh. BMC Infectious Diseases 2010; 10: 208 .

31. Mahtab MA, Rahman S, Karim F, Foster G, Solaiman S. Epidemiology of hepatitis $\mathrm{C}$ virus in Bangladeshi general population. BSMMU J 2009; 2(1): 14-17.

32. Gibney L, Saquib N, Metzger J, Choudhury P, Siddiqui M, Hassan M. Human immunodeficiency virus, hepatitis B, C and $\mathrm{D}$ in Bangladesh's trucking industry: prevalence and risk factors. Int J Epidemiol 2001; 30: 878-884.
33. Bogaerts J, Ahmed J, Akhter N, Begum N, Rahman M, Nahar $\mathrm{S}$ et al. Sexually transmitted infections among married women in Dhaka, Bangladesh: unexpected high prevalence of herpes simplex type 2 infection. Sex Transm Infect 2001; 77: 114-119.

34. Gibney L, Macaluso M, Kirk K, Hassan MS, Schwebke J, Vermund $\mathrm{SH}$ et al. Prevalence of infectious diseases in Bangladeshi women living adjacent to a truck stand: HIV/STD/hepatitis/genital tract infections. Sex Transm Infect 2001; 77: 344-750.

35. Shirin T, Ahmed T, Iqbal A, Islam M, Islam MN. Prevalence and risk factors of hepatitis $\mathrm{B}$ virus, hepatitis $\mathrm{C}$ virus, and human immunodeficiency virus infections among drug addicts in Bangladesh. J Health Popul Nutr 2000; 18: 145-150.

36. Khan WI, Sultana R, Rahman M, Akhter H, Haq JA, Ali L et al. Viral hepatitis: recent experiences from serological studies in Bangladesh. Asian Pac J Allergy Immunol 2000; 18: 99-103.

37. Ghany MG, Strader DB, Thomas DL, Seeff LBI. American association for the study of liver diseases, diagnosis, management, and treatment of hepatitis $\mathrm{C}$ : an update. Hepatology 2009; 49(4): 1335-1374.

38. Das MR, Ali N, Aruna B, Rama D, Nambiar A, Rehana Z et al. Indian strains of hepatitis $\mathrm{C}$ : prevalence and detection. Curr Sci 1993; 65: 477-483.

39. Khaja MN, Munpally SK, Hussain MM, Habeibullah CM. Hepatitis C virus: the Indian scenario. Curr Sci 2002; 83: 219-224.

40. Chandra M, Khaja MN, Hussain MM, Poduri CD, Farees N, Habeeb MA et al. Prevalence of hepatitis B and hepatitis C viral infections in Indian patients with chronic renal failure. Intervirology 2004; 47(6): 374-376.

41. Turgut H, Turhanoðlu M, Aydýn K, Arýkan E, Degertekin H, Ariturk S. Anti-HCV positivity in different groups (in Turkish). J Gastroenterol 1992; 3: 640-642.

42. Islam MN, Hossain RM, Rahman MH, Mansur MA, Hassan MS, Islam MS et al. Hepatitis B (HBV) and C (HCV) among maintenance hemodialysis patients, family members and dialysis staffs. Abstract from $27^{\text {th }}$ Annual Dialysis Conference. Hemodialysis International 2007; 11(1): 108.

43. Sultana S, Ali MK, Shaha AK, Khan NN, Husain MA. Evaluation of antibody response against hepatitis $\mathrm{C}$ virus infection in patients on maintenance hemodialysis (mhd): a pilot study. Bangladesh J Med Biochem 2014; 7(1): 9-13.

44. Richter SS. Laboratory assays for diagnosis and management of hepatitis C virus infection. J Clin Microbiol 2002; 40: 4407-4412. 